\title{
How CEO Wealth Affects the Riskiness of a Firm
}

\author{
Sonik Mandal ${ }^{1}$, Charlie Swartz ${ }^{1}$, Sanjib Guha ${ }^{2} \&$ Carl B. McGowan, Jr. ${ }^{2}$ \\ ${ }^{1}$ Storme School of Business, Old Dominion University, Norfolk, UK \\ ${ }^{2}$ School of Business, Norfolk State University, Norfolk, UK \\ Correspondence: Carl B. McGowan, Jr., School of Business, Norfolk State University, Norfolk, UK.
}

Received: October 27, 2016

doi:10.11114/aef.v6i4.4319
Accepted: November 28, $2016 \quad$ Available online: June 9, 2019

URL: https://doi.org/10.11114/aef.v6i4.4319

\begin{abstract}
The objective of this paper is to analyze the relationship between the ownership level of managers and the risk averse behavior of the firm. We measure the ownership level of the managers by the ratio of their ownership of the company relative to their total wealth for a sample of 69 individuals from the Forbes 400 list of the wealthiest individuals in the world for the period from 2001-11 using an unbalanced panel data analysis. The dependent variable is the Altman $Z$-score of each firm and we further test these relationships using financial leverage. The independent variables are delta and Vega of the option portfolio of the manager, $R \& D$ for the firm, total assets, the age of the manager, the tenure of the manager, stock holding of the manager, $\mathrm{CEO} /$ Chair duality of the manager and firma age. The Z-score is statistically significantly related to size, CEO age, CEO wealth, and duality. Financial leverage is not statistically significantly related to any of the independent variables.
\end{abstract}

Keywords: $\mathrm{CEO}$ wealth effect, firm riskiness, unbalanced panel data analysis, Altman Z-score

\section{Introduction}

Agency theory argues that the objectives of the owners or a firm and the managers of a firm may diverge such that managers assume less risk because the managers degree of ownership in the firm is substantially less than the ownership level in the firm of the owners since the owners have a substantially larger degree of ownership in the firm. Since the managers are risk averse the managers often turn down potentially profitable investments if the managers perceive that the investments that are foregone are perceived to be more risky (Guay, 1999, Jensen \& Meckling, 1976). The perceived risk aversion of the manager makes the salary and bonus agreement between managers and owners more complicated through the introduction of additional option-based compensation. Stock award compensation is one way owners endeavor to align the goals of the managers with the goals of the owners. However, managerial wealth invested in the firm is likely to be only a small fraction of the manager's total personal wealth portfolio. Other components of a manager's total wealth portfolio could consist of stocks ownership in other firms, real estate investment, and fixed income securities included in the manager's investment portfolio.

Research has been done to examine the relationship between the structure of managerial compensation, such as stock options and stock awards, and how the compensation structure might influence the manger's willingness to assume additional risk even when the additional returns are adequate (Knopf et al. 2002, Rogers, 2002).However, little research has been done linking a manager's wealth outside the firm and the manager's risk taking in the firm where the manager is employed. Elsila et al. 201 analyzed the relationship between manager compensation structure and a manager's willingness to assume risk. Elsila et al. 201 analyzed managers in Swedish stock exchange listed firms. The authors found a positive relationship between the level of manager ownership in the firm and risk taking that is the authors found that managers with a higher proportion of wealth invested in the firm where they were employed, the less risk the manager would be willing to assume.

We use a "wealth ratio" defined as the proportion of the manager's total personal wealth invested in the company that is the amount of wealth invested by the manager in the firm divided by the total amount of wealth of the manager. Knopf et al. 2002 and Rogers, 2002, show using option pricing theory that a higher delta corresponds to more risk taking on the part of the manager and a higher Vega of the option portfolio of the manager corresponds to less risk taking on the part of the manager. But the relationship of delta and Vega of the option portfolio with the risk variable when the wealth ratio as an independent variable has not been examined. This paper contributes to the literature in the following ways: 
First, no previous paper has looked at the effect of the wealth ratio on risk in US listed firms. Second, most past literature have emphasized the importance of effective compensation structure to affect the managers' risk appetite, but no paper have looked upon the total outside wealth of the managers portfolio and how that relationship affects the manager's decision making process.

\section{Theory Development}

\subsection{Total Personal Wealth of the Manager and Risk Aversion}

A manager's total wealth is equal to the total amount of wealth invested in the firm plus the total wealth invested outside the firm. Manager's wealth in the company includes any stock holdings (preferred and common), option holdings, and debt holdings. Outside wealth of the manager includes stock and debt holdings of other companies, any real estate holdings, such as REITs. Similar to Elsila et al. 2013, we are use the wealth ratio variable to determine the risk aversion of the manager. The wealth ratio is defined as the ratio of the wealth invested in the firm to the total wealth of the manager. The higher the wealth ratio the higher the risk aversion of the manager. This is consistent with previous literature predicting that managers whose incentives are tied more closely to the firm are risk averse (Jensen \& Meckling, 1976; Berle \& Means, 1932). Incentives awarded in the form of options makes the compensation structure more convex thus making the manager less risk averse (Rogers, 2002, Chen et al. 2006).

\section{Variables Description}

\subsection{Dependent Variable}

Our main dependent variable is the Z-Score of a firm. It was famously used by Edward Altman to predict the likelihood of bankruptcy for a firm. (Altman, 1968) The Z-score ratio combines several liquidity, profitability, and efficiency ratios to arrive at a final value. Creditors use the model to assess financial distress. A lower score indicates a higher probability of distress. It is a good measure for the riskiness of a firm because it combines several ratios and will therefore capture a wider spectrum of firm risk. In addition, financial leverage is used as a dependent variable in this paper to be consistent with the previous literature. Financial leverage is defined as the ratio of the total debt of the company to the total assets. The higher the financial leverage, the greater is the risk profile of the company.

\subsection{Independent Variable}

Our main independent variable is the wealth ratio. This variable is defined as the ratio of the wealth invested in the company to the total personal wealth of the executive. The higher the wealth ratio the more would be risk averse the manager, and thus the lower would be the financial and operating leverage of the company.

\subsection{Control Variables}

\subsubsection{Delta and Vega of the Option Portfolio of the Manager}

Delta of the managers' option portfolio refers to the sensitivity of the option price with the stock price of the firm while the Vega is defined as the sensitivity of the option price with the volatility of the stock. These two ratios have opposite effects on a manager's decision making; delta of the option portfolio corresponds to risk aversion by the manager while the Vega of the portfolio is related to more risk taking by the manager (Knopf et al. 2002, Rogers, 2002). Thus, we would expect a positive relationship between the delta and the leverage variables but a negative relationship between Vega and the leverage variables.

\subsubsection{R\&D Activities}

This variable is defined as the ratio of the R\&D expenses of the firm to the total assets of the firm. Firms with a higher $R \& D$ expenditure would have a higher risk profile and so we expect a positive relationship between $R \& D$ activities and leverage ratios.

\subsubsection{Total Assets}

To control for firm size, we use the log of the total assets of the firm. We expect a positive relationship between the risk leverage ratios and the total assets variable.

\subsubsection{Age of the Manager}

This variable is defined as the log of the age of the manager. We would expect a negative relationship between age and the risk leverage variables since with age managers would become more conservative and try to preserve their existing wealth.

\subsubsection{Tenure as CEO/Executive Position}

This variable is defined as the log of the tenure of the manager in his executive position. The higher the tenure of the manager more would be the experience of the manager at the current position, and so more the manager would be efficient in maintaining a stable risk profile of the firm. Thus, we would expect a negative relationship between the 
tenure as a manager and the risk leverage ratios.

\subsubsection{Stock Holdings of the CEO}

This variable is defined as the log of the stock holdings of the CEO in the firm. We would expect a positive relationship between stock holdings of the manager and the risk leverage ratios of the firm.

\subsubsection{Duality of the CEO/Manager}

This variable is defined as a binary variable, which is equal to one if the CEO is also the chairman of the board and zero otherwise. We would expect a negative relationship between the duality variable and the risk leverage ratios, as when the manager/ CEO is also the chairman of the board, he would be more responsible for his decisions, and so would be more risk-averse, and so would take on less debt and would be more flexible in his daily activities.

\subsubsection{Firm Age}

This variable is defined as the log of the difference of the founding date of the company and the respective years analyzed in the paper. We would expect a positive relationship between the firm age and the risk leverage ratios since more mature companies would have higher debt and higher capital expenditures compared to younger firms.

\section{Methods}

Unlike in Sweden where CEO wealth data is publically available (Becker 2006), the US values privacy and that information is protected. This desire for privacy may explain why there is a lack of research using CEO wealth as an explanatory variable for firm characteristics. In this paper, we use wealth data collected from Forbes magazine in their annual Forbes 400 edition that highlights the wealthiest 400 individuals in the United States and their estimated wealth. We cross checked those articles with the Execucomp database to provide a list of CEOs wealth data across time. The final sample from 2001-2011 consists of 69 individuals and 311 unique firm year observations for this panel set. The data needed to be corrected for heteroskedascity and a fixed-effects model was used. Since it is an unbalanced panel, a first difference model would not work. Using a between effects model allows us to implement a fixed effects model in an unbalanced set. A combination of Bloomberg and Compustat databases were matched with the CEOs to obtain firm level variables. Delta was calculated on the cut-off days for the Forbes wealth calculations and gives an accurate picture of how sensitive the CEO's wealth is to a change in stock price. (Core and Guay 2002)

\section{Empirical Results}

The main regression is summarized in Table 1. As you can see the firms Z-Score is statistically significantly positively related to CEO wealth and the duality dummy variable, meaning a firm is less likely to go into bankruptcy the more wealthy a CEO and if he is also the chairman, though it is negatively related to CEO age. The sensitivity of the CEO wealth to stock price changes shows no relation to the companies Z-Score. In Table 2, we look at a firm's financial leverage and find that it is the CEOs outside wealth that is negatively related to the amount of leverage, no other variables showed a statistically significant relationship.

Table 1. Fixed Effects Regression on Z-Score

\begin{tabular}{llll}
\hline & Coefficient & T Score & \\
\hline Constant & 98.912 & 1.89 & $*$ \\
Sales & -5.274 & -3.74 & $* * *$ \\
CEO Age & -29.055 & -2.02 & $* *$ \\
CEO Tenure & -0.737 & -0.58 & \\
CEO Wealth & 4.915 & 2.60 & $* * *$ \\
Outside Wealth \% & -2.466 & -0.88 & \\
Delta & 0.219 & 0.87 & $* *$ \\
Duality & 3.008 & 2.39 & \\
$\mathrm{R}^{2}$ & 0.1932 & & \\
$\mathrm{~N}$ & 311 & & \\
$* 10 \%, * * 5 \%, * * * 1 \%$ & & & \\
\hline
\end{tabular}


Table 2. Fixed Effects Regression on Financial Leverage

\begin{tabular}{llll}
\hline & Coefficient & T Score & $*$ \\
\hline Constant & 50.728 & 1.74 & \\
Sales & 0.512 & 0.59 & \\
CEO Age & -6.457 & -1.31 & \\
CEO Tenure & 0.599 & 0.44 & \\
CEO Wealth & -0.779 & -0.71 & \\
Outside Wealth \% & -7.861 & 1.90 & -0.71 \\
Delta & -0.459 & -0.54 & \\
Duality & -1.828 & \\
$\mathrm{R}^{2}$ & 0.1932 & & \\
$\mathrm{~N}$ & 311 & & \\
$* 10 \%, * * 5 \%, * * 1 \%$ & & & \\
\hline
\end{tabular}

\section{Discussion}

The main empirical results of this study point to CEOs running less risky firms as they become wealthier. Though these ratios hardly make up the entire risk profile of a company they provide a relatively good starting point to show how healthy a firm's balance sheet may be. The Z-score in particular is an amalgam of several ratios and will point out weaknesses in a company's financials. The lack of significant variables in determining an optimal financial leverage point leads one to believe that the CEO level variables are a poor predictor for the amount of debt a firm may carry. Though the significance of outside wealth is interesting because it implies that the less dependent a CEO is on the success of his firm implies that he is taking less risks. While the firm has less debt in the form of financial leverage, the firm may not be maximizing the use of its resources. The firm could have a difficult time incentivizing the CEO to pursue risky strategies and exploit its access to credit markets. This could be especially true in our sample that only consists of billionaires. The results though may not be very generalizable because we are dealing with a heavily truncated wealth data set. The sample only consists of very wealthy individuals, though we still find statistically significant results suggesting whatever relationship between CEO wealth and firm risk holds at the upper ends of the wealth spectrum. The results would seem to support agency theory in which it is difficult to align the interests of the $\mathrm{CEO}$ and the firm, though only through lack of risk-taking. Since they have accumulated a large, amount of wealth, their risk aversion may have increased and their focus shifted to preservation of wealth. A follow-up study on the relationship of wealth and performance would show whether a firm is able to obtain similar returns while taking on much less risk, which would point to wealthier CEOs possessing superior skill, though if that is not the case then firms face a challenge of incentivizing wealthy CEOs to take risks and take full advantage of a firms leverage capabilities.

\section{References}

Altman, E. I. (1968). Financial ratios, discriminant analysis and the prediction of corporate bankruptcy. The journal of finance, 23(4), 589-609. https://doi.org/10.1111/j.1540-6261.1968.tb00843.x

Becker, B. (2006). Wealth and executive compensation. The Journal of Finance, 61(1), 379-397. https://doi.org/10.1111/j.1540-6261.2006.00839.x

Berle, A., \& Means, G. (1932). The Modern Corporation and private property. Harcourt, Brace \& World, New York, NY.

Chen, C., Steiner, T., \& Whyte, A. (2006). Does stock option-based executive compensation induce risk-taking? An analysis of the banking industry. Journal of Banking and Finance, 30, 915-945. https://doi.org/10.1016/j.jbankfin.2005.06.004

Core, J., \& Guay, W. (2002). Estimating the value of employee stock option portfolios and their sensitivities to price and volatility. Journal of Accounting Research, 40(3), 613-630. https://doi.org/10.1111/1475-679X.00064

Elsila, A., Kallunki, J., Nilsson, H., \& Sahlstrom, P. (2013). CEO personal wealth, equity incentives and firm performance. Corporate Governance: An International Review, 21(1), 26-41. https://doi.org/10.1111/corg.12001

Guay, W. (1999). The sensitivity of CEO wealth to equity risk: an analysis of the magnitude and determinants. Journal of Financial Economics, 53(1), 43-71. https://doi.org/10.1016/S0304-405X(99)00016-1

Michael, C. J., \& William, H. M. (1976). Theory of the firm: managerial behavior, agency costs and ownership structure. 
Journal of Financial Economics, 3, 305-360. https://doi.org/10.1016/0304-405X(76)90026-X

Knopf, J., Nam, J., \& Thornton, J. (2002). The volatility and price sensitivities of managerial stock option portfolios and corporate hedging. Journal of Finance, 57(2), 801-813. https://doi.org/10.1111/1540-6261.00442

Lev, B. (1974). On the association between operating leverage and risk. Journal of Financial and Quantitative analysis, 9(4), 627-641. https://doi.org/10.2307/2329764

Rogers, D. (2002). Does executive portfolio structure affect risk management? CEO risk-taking incentives and corporate derivatives usage, Journal of Banking and Finance, 26(2), 271-295. https://doi.org/10.1016/S0378-4266(01)00222-9

Saunders, A., Strock, E., \& Travlos, N. (1990). Ownership structure, deregulation, and bank risk taking. The Journal of Finance, 45(2). 643-654. https://doi.org/10.1111/j.1540-6261.1990.tb03709.x

\section{Copyrights}

Copyright for this article is retained by the author(s), with first publication rights granted to the journal.

This is an open-access article distributed under the terms and conditions of the Creative Commons Attribution license which permits unrestricted use, distribution, and reproduction in any medium, provided the original work is properly cited. 